\title{
Evaluation of Endocrine Late Complications in Childhood Acute Lymphoblastic Leukemia Survivors: A Report of a Single-Center Experience and Review of the Literature
}

\author{
Akut Lenfoblastik Lösemili Çocuklarda Endokrin Geç Komplikasyonların Değerlendirilmesi: \\ Tek Merkez Deneyimi ve Literatür Derlemesi
}

\author{
Cengiz Bayram¹, Neşe Yaralı1, Ali Fettah1, Fatma Demirel2, Betül Tavil1, Abdurrahman Kara1, Bahattin Tunç¹ \\ ${ }^{1}$ Ankara Children's Hematology and Oncology Hospital, Clinic of Pediatric Hematology, Ankara, Turkey \\ 2 Private Doctor
}

\section{Abstract}

Objective: Improvement in long-term survival in patients with acute lymphoblastic leukemia (ALL) in childhood has led to the need for monitorization of treatment-related morbidity and mortality. In the current study, we aimed to evaluate endocrine side effects of treatment in ALL survivors who were in remission for at least 2 years.

Materials and Methods: Sixty patients diagnosed with $A L L$, who were in remission for at least 2 years, were cross-sectionally evaluated for long-term endocrine complications.

Results: The median age of the patients at the time of diagnosis, at the time of chemotherapy completion, and at the time of the study was 5 years (minimum-maximum: 1.7-13), 8 years (minimummaximum: 4.25-16), and 11.7 years (minimum-maximum: 7-22), respectively, and median follow-up time was 4 years (minimummaximum: 2-10.1). At least one complication was observed in $81.6 \%$ of patients. Vitamin D insufficiency/deficiency (46.6\%), overweight/ obesity (33.3\%), and dyslipidemia (23.3\%) were the three most frequent endocrine complications. Other complications seen in our patients were hyperparathyroidism secondary to vitamin $D$ deficiency (15\%), insulin resistance (11.7\%), hypertension (8.3\%), short stature $(6.7 \%)$, thyroid function abnormality $(5 \%)$, precocious puberty $(3.3 \%)$, and decreased bone mineral density (1.7\%). There were no statistically significant correlations between endocrine complications and age, sex, and radiotherapy, except vitamin D insufficiency/deficiency, which was significantly more frequent in pubertal ALL survivors compared to prepubertal ALL survivors (57.5\% and $25 \%$, respectively, $p=0.011$ ).

Conclusion: A high frequency of endocrine complications was observed in the current study. The high frequency of late effects necessitates long-term surveillance of this population to better understand the incidence of late-occurring events and the defining of high-risk features that can facilitate developing intervention strategies for early detection and prevention.

Keywords: Acute lymphoblastic leukemia, Endocrine, Late effects, Children

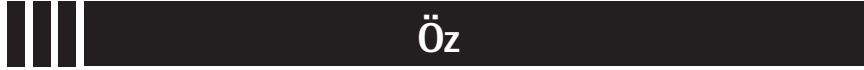

Amaç: Akut lenfoblastik lösemili (ALL) hastalardaki sağ kalım oranlarının artışı, tedavi sonrası ortaya çıkan morbidite ve mortalite problemlerinin takip edilme intiyacını beraberinde getirmiştir. Çalışmamızda, en az iki yıldır remisyonda olan ALL'li hastalarda, tedavi sonrası ortaya çıkabilecek endokrin komplikasyonların değerlendirilmesi amaçlandı.

Gereç ve Yöntemler: ALL tanısı ile tedavi almış ve tedavisi üzerinden en az iki yıl geçmiş ve remisyonda olan 60 hastada endokrin geç komplikasyonlar kesitsel olarak değerlendirildi.

Bulgular: Hastaların tanı aldıkları andaki median yaşları 5 yıl (minimum-maksimum: 1,7-13), kemoterapi sonlandırıldığı andaki median yaşları 8 yıl (minimum-maksimum: 4,25-16), çalışma sırasındaki median yaşları ise 11,7 yıl (minimum-maksimum: 7-22) olarak tespit edildi. Hastaların tedavi sonrası median takip süresi ise 4 yıl (minimum-maksimum: 2-10,1) idi. Hastaların \%81,6'sında en az bir endokrin komplikasyon geliştiği görüldü. D vitamini eksikliği/ yetersizliği $(\% 46,6)$, obezite/fazla kiloluluk $(\% 33,3)$ ve dislipidemi $(\% 23,3)$ en sık gelişen üç komplikasyon olarak tespit edildi. D vitamini eksikliğine sekonder gelişen hiperparatiroidi (\%15), insülin direnci $(\% 11,7)$, hipertansiyon $(\% 8,3)$, boy kısalığı $(\% 6,7)$, tiroid fonksiyon bozukluğu $(\% 5)$, puberte prekoks $(\% 3,3)$ ve azalmış kemik mineral yoğunluğu $(\% 1,7)$ gelişen diğer endokrin komplikasyonlardı. Hastalarda gelişen endokrin komplikasyonlar arasında cinsiyet, yaş, radyoterapi bakımından farklılık saptanmaz iken, D vitamini yetersizliği/eksikliği saptanan hasta sayısı pubertal grupta, prepubertal gruba göre anlamlı derecede fazlaydı (\%57,5 ve \%25, sırasıyla, $p=0,011)$.

Sonuç: Çalışmamızda yüksek oranda endokrin komplikasyon saptandı. Bu komplikasyonlar, geç yan etkilerin ortaya çıkmasına neden olabilecek yüksek risk özellikleri ve sıklığı tanımlayabilmek, erken tanı ve önleyici stratejileri geliştirmek açısından hastaların uzun dönem izlenmelerini gerektirmektedir.

Anahtar Sözcükler: Akut lenfoblastik lösemi, Endokrin, Geç yan etkiler, Çocuk 


\section{Introduction}

Despite the increase in the prevalence of childhood malignancies, the 5-year survival rate for acute lymphoblastic leukemia (ALL) in childhood has approached $90 \%$ as a result of advances in chemotherapy and supportive care. This increase in survival has increased the importance of long-term treatment-related morbidity and mortality [1]. One of the consequences of cancer or its therapy is that many long-term survivors of childhood cancer are at an increased risk of developing chronic physical or psychosocial problem [2]. It is estimated that about two-thirds of cancer survivors will experience at least one late adverse effect and more than $40 \%$ may have a severe, disabling, or lifethreatening condition or may die 30 years after the cancer is diagnosed [3]. There have been numerous chemotherapy agents used for the treatment of ALL; however, a few of them have been implicated as causing late effects, including anthracyclines (e.g., doxorubicin, daunorubicin), oxazaphosphorine alkylating agents (e.g., cyclophosphamide), corticosteroids (e.g., prednisone, dexamethasone), and high-dose methotrexate [2]. The adverse effects of prophylactic cranial irradiation, including acute neurotoxicity, neurocognitive deficits, endocrinopathies, secondary malignant disease, and excess late mortality, have led to its reduction or elimination from treatment protocols for ALL $[4,5,6]$.

Endocrine complications during therapy for ALL include bone demineralization, disordered growth, adrenocortical insufficiency, diabetes mellitus, the syndrome of inappropriate secretion of antidiuretic hormone, and changes in thyroid hormone concentration, whereas late complications, those that occur after completion of all radiation and chemotherapy, include bone demineralization, short stature, growth hormone deficiency, obesity, hypothyroidism, gonadal dysfunction, and infertility [7]. The present study aimed to evaluate long-term endocrine complications in ALL survivors that were in remission for at least 2 years.

\section{Materials and Methods}

Sixty patients diagnosed with ALL between January 2003 and February 2009 at the Pediatric Hematology Clinic of Ankara Children's Hematology and Oncology Education and Research Hospital, who were in remission for at least 2 years, were included in the study and were evaluated cross-sectionally. All patients with ALL were treated according to the St. Jude TotalXIIIA protocol [8] and received 12 or $18 \mathrm{cGy}$ cranial radiotherapy (CRT) as a part of prophylaxis or treatment as appropriate.

Pubertal status was assessed at the time of the study using Tanner staging and patients were divided into two groups as pubertal or prepubertal. Body weight and height were measured and evaluated according to Turkish children's growth data [9].
Body mass index (BMI) was calculated as weight in kilograms divided by the square of the height in meters. Overweight was defined as BMl for age and sex between the $85^{\text {th }}$ and $95^{\text {th }}$ percentiles, and BMI for age and sex higher than the $95^{\text {th }}$ percentile was defined as obesity.

Hormonal analysis was carried out by the chemiluminescence method using a BIO-DPC hormone autoanalyzer with commercial kits, and a Roche/Hitachi Modular P Chemistry Analyzer was used for biochemical analysis. Serum lipid profiles, including cholesterol, triglyceride, low-density lipoprotein cholesterol (LDL-C), high-density lipoprotein cholesterol (HDL-C), and blood glucose, were obtained after at least $8 \mathrm{~h}$ of fasting. Dyslipidemia was defined as cholesterol of $>200 \mathrm{mg} / \mathrm{dL}$, or triglyceride of $>150 \mathrm{mg} / \mathrm{dL}$, or LDL-C of $>130 \mathrm{mg} / \mathrm{dL}$, or HDL-C of $<40$ [10]. The homeostasis model assessment (HOMA) score was calculated using the following formula: [fasting glucose $(\mathrm{mmol} / \mathrm{L}) \times$ insulin (mmol/L)]/22.5. A HOMA score above 2.5 for prepubertal patients and above 3.2 for pubertal patients was accepted as evidence of insulin resistance $[11,12]$. Metabolic syndrome was defined as the presence of three or more of the following: 1) hypertension, 2) glucose intolerance, 3) hypertriglyceridemia, 4) decreased HDL level, and 5) central abdominal obesity [13]. Low free thyroxine (T4) and thyroid-stimulating hormone (TSH) level of $>10 \mu \mathrm{U} / \mathrm{mL}$ with clinical symptoms were defined as hypothyroidism, and normal free T4 level and TSH level between 5 and $10 \mu \mathrm{U} / \mathrm{mL}$ without clinical symptoms were defined as subclinical (compensated) hypothyroidism [14]. Parathyroid hormone (PTH) values between 6 and $65 \mathrm{pg} / \mathrm{mL}$ were accepted as normal. High PTH levels with vitamin D deficiency were diagnosed as "secondary hyperparathyroidism". Patients having hypocalcemia, hyperphosphatemia, and decreased PTH levels were diagnosed with "primary hypoparathyroidism". Serum adrenocorticotropic hormone (ACTH) and cortisol levels were simultaneously measured at 09:00 hours. ACTH levels between 7 and $28 \mathrm{pg} / \mathrm{mL}$ for prepubertal children and between 2 and $49 \mathrm{pg} / \mathrm{mL}$ for postpubertal children were accepted as normal. Cortisol levels between 8 and $22 \mu \mathrm{g} / \mathrm{dL}$ were accepted as normal, whereas $<8 \mu \mathrm{g} / \mathrm{dL}$ was accepted as adrenal insufficiency [15]. Serum 25-OH-vitamin D levels less than $15 \mathrm{ng} / \mathrm{mL}$ were diagnosed as a sign of vitamin D deficiency (normal: 20-100 $\mathrm{ng} / \mathrm{mL}$ ) and values between 15 and $20 \mathrm{ng} / \mathrm{mL}$ were considered as vitamin $D$ insufficiency [16]. Bone mineral density (BMD) was measured by using dual energy $\mathrm{X}$-ray absorptiometry from the L1-L4 lumbar vertebrae and was assessed according to bone ages appropriately for Turkish children's data [17]. Ageand sex-adjusted Z-scores of less than -2 were considered as evidence of decreased BMD.

The study was approved by the hospital ethics committee, and informed consent was obtained from the parents of all participating subjects. 
Continuous variables are expressed as median (minimummaximum) and categorical variables as number (percentage). The clinical parameters and laboratory values of the patients were evaluated using the chi-square method and Student's t-test, as appropriate. All statistical tests were two-sided and $\mathrm{p}<0.05$ was considered statistically significant. Statistical analysis was performed using SPSS 18.0 for Windows (SPSS Inc., Chicago, IL, USA).

\section{Results}

Of the 60 ALL survivors, 31 (51.7\%) were male and 29 (48.3\%) were female. Fifty-five patients (91.7\%) were diagnosed with pre-B-cell ALL and five (8.3\%) were diagnosed with T-cell ALL. Overall, 21 patients (35\%) received 12 or $18 \mathrm{cGy}$ CRT as a part of prophylaxis or treatment as appropriate. The median age of the patients at the time of diagnosis, at the time of chemotherapy completion, and at the time of the study was 5 years (minimummaximum: 1.7-13), 8 years (minimum-maximum: $4.25-16$ ), and 11.7 years (minimum-maximum: 7-22), respectively, and median follow-up time was 4 years (minimum-maximum: 2-10.1). Demographic data of patients are summarized in Table 1.

One or more adverse events occurred in $81.6 \%$ of the $60 \mathrm{ALL}$ survivors; 25 patients (41.6\%) had one endocrine complication, 17 patients $(28.3 \%)$ had two endocrine complications, 5 patients $(8.3 \%)$ had three endocrine complications, and 2 patients (3.3\%) had four endocrine complications. Vitamin D insufficiency/deficiency (46.6\%), overweight/obesity (33.3\%), and dyslipidemia (23.3\%) were the three most frequent endocrine complications, followed by hyperparathyroidism

\begin{tabular}{|c|c|}
\hline \multicolumn{2}{|l|}{ Sex, n (\%) } \\
\hline Male & $31(51.7)$ \\
\hline Female & 29 (48.3) \\
\hline \multicolumn{2}{|l|}{ Leukemia type, n (\%) } \\
\hline B-cell & $55(91.7)$ \\
\hline T-cell & $5(8.3)$ \\
\hline \multicolumn{2}{|l|}{ Median age, years (minimum-maximum) } \\
\hline At the time of diagnosis & $5(1.7-13)$ \\
\hline At the time of chemotherapy completion & $8(4.25-16)$ \\
\hline At the time of the study & $11.7(7-22)$ \\
\hline Median follow-up time, years (range) & $4(2-10.1)$ \\
\hline \multicolumn{2}{|l|}{ Chemotherapy protocol, n (\%) } \\
\hline St. Jude Total-XIIIA protocol & $60(100)$ \\
\hline \multicolumn{2}{|l|}{ Cranial radiotherapy, $\mathrm{n}(\%)$} \\
\hline $\mathrm{CRT}^{+}$ & $21(35)$ \\
\hline $\mathrm{CRT}^{-}$ & $39(65)$ \\
\hline
\end{tabular}

secondary to vitamin D deficiency $(15 \%)$, insulin resistance $(11.7 \%)$, hypertension $(8.3 \%)$, short stature $(6.7 \%)$, thyroid function abnormality (5\%), precocious puberty (3.3\%), and decreased BMD (1.7\%). There were no patients diagnosed with adrenal insufficiency, as serum ACTH and cortisol levels were within the normal ranges for all patients (Table 2).

There were four patients (6.6\%) with three components of metabolic syndrome, seven patients $(11.6 \%)$ with two components of metabolic syndrome, and 18 patients (30\%) with one component of metabolic syndrome. Of the seven patients with insulin resistance, five had overweight or obesity, and two patients had normal BMI.

In the present study, long-term endocrine complications in 60 ALL survivors were also assessed with respect to age $(<5$ years versus $>5$ years), sex (male versus female), pubertal status (pubertal versus prepubertal), and either CRT administered or not. No significant differences were observed with respect to age, sex, and cranial radiotherapy, whereas vitamin D insufficiency/deficiency was significantly more frequent in pubertal ALL survivors (57.5\%) as compared to prepubertal ALL survivors (25\%) (Table 3).

\section{Discussion}

Despite the increase in the prevalence of childhood cancer, with a $0.6 \%$ increase in incidence rates for all childhood cancers noted during 1975-2002, a reduction in the mortality rate has been achieved through multimodal chemotherapy and enhanced supportive care [18]. However, as a consequence of treatment-related complications, recurrence of primary cancer, and subsequent malignancies, approximately two-thirds of this population is reported to have one or more late adverse effects $[18,19,20,21]$. In concordance with previous reports, one or more adverse events occurred in $81.6 \%$ of the present study's ALL survivors. Vitamin D insufficiency/deficiency $(46.6 \%)$ was the most frequent endocrine complication in the current study. ALL survivors are at increased risk of developing

\begin{tabular}{|l|l|}
\hline Table 2. Endocrine complications. & $\mathbf{n = 6 0}$ \\
\hline Endocrine complications, $\mathbf{n}(\mathbf{\%})$ & $28(46.6)$ \\
\hline Vitamin D insufficiency/deficiency & $20(33.3)$ \\
\hline Overweight/obesity & $14(23.3)$ \\
\hline Dyslipidemia & $9(15)$ \\
\hline Hyperparathyroidism secondary to vitamin D deficiency & $7(11.7)$ \\
\hline Insulin resistance & $5(8.3)$ \\
\hline Hypertension & $4(6.6)$ \\
\hline Short stature & $3(5)$ \\
\hline Thyroid function abnormality & $2(3.3)$ \\
\hline Precocious puberty & $1(1.7)$ \\
\hline Decreased bone mineral density &
\end{tabular}




\begin{tabular}{|c|c|c|c|c|}
\hline Endocrine complications, n (\%) & Total $(n=60)$ & Pubertal $(n=40)$ & Prepubertal $(n=20)$ & p \\
\hline Vitamin D insufficiency/deficiency & $28(46.6)$ & $23(57.5)$ & $5(25)$ & $0.011^{*}$ \\
\hline Overweight/obesity & $20(33.3)$ & $12(30)$ & $8(40)$ & 0.439 \\
\hline Dyslipidemia & $14(23.3)$ & $10(25)$ & $4(20)$ & 0.666 \\
\hline Hyperparathyroidism secondary to vitamin D deficiency & $9(15)$ & $7(17.9)$ & $2(10)$ & 0.443 \\
\hline Insulin resistance & $7(11.7)$ & $5(12.5)$ & $2(10)$ & 0.591 \\
\hline Hypertension & $5(8.3)$ & $4(10)$ & $1(5)$ & 0.509 \\
\hline Short stature & $4(6.6)$ & $2(5)$ & $2(10)$ & 0.464 \\
\hline Thyroid function abnormality & $1(1.7)$ & $2(5)$ & $1(5)$ & 1 \\
\hline *Significant. & & & & \\
\hline
\end{tabular}

BMD deficits compared to the general population, associated with their treatment, including high cumulative doses of steroids/methotrexate and radiation therapy. Because vitamin $D$ has a positive influence on calcium balance for building bone and attaining peak bone mass, vitamin D deficiency or insufficiency can contribute to BMD deficit [22]. The prevalence of 25-hydroxyvitamin D (25-OH-D) insufficiency is reported to be $14-49 \%$ in the general population and was reported to be between $33.5 \%$ and $40 \%$ in healthy Turkish children and adolescents in two recent studies $[23,24,25,26]$. In a recent study of 484 childhood cancer survivors, $17.6 \%$ of whom had leukemia, Choudhary et al. reported a prevalence of 29\% of 25-OH-D insufficiency, and the risk factors for 25-OH-D insufficiency were race, pubertal status, and seasonality [27]. The prevalence of 25-OH-D deficiency or insufficiency was $46.6 \%$ in our study, which was higher than in the latter study and two recent studies from Turkey but similar to what has been described in the general population. Pubertal status was the only significant risk factor in the present study, while 23 of 28 patients (82.1\%) with 25-OH-D deficiency or insufficiency were pubertal ALL survivors. Forty percent of bone mass is obtained during puberty, and by the end of puberty, 90\% of total adult bone mass has already been acquired in the normal population [22]. In this regard, in addition to chemotherapy agents and radiation therapy, 25-OH-D deficiency or insufficiency can additionally contribute to failure to recover to a normal BMD after completion of therapy, and thus surveillance and intervention strategies should also include assessment of 25$\mathrm{OH}-\mathrm{D}$ levels during puberty.

Overweight or obesity has been identified as a potential late adverse effect of therapy in childhood ALL survivors $[2,3]$. The largest study evaluating the risk of being overweight in ALL survivors was conducted by the Childhood Survivor Cancer Study. That study showed that survivors who received greater than 20 Gy CRT were significantly more likely than their siblings to be overweight, and female survivors treated before the age of 4 years were also more likely to be overweight in comparison with siblings [28]. Studies about the risk of being overweight or obese in ALL survivors have conflicting results. In a study of 618 ALL survivors, reported by Dalton et al., they found that children treated before the age of 13 years had a significant decrease in their height z-scores and an increase in their BMI z-scores, regardless of cranial radiation therapy [29]. Razzouk et al. observed that young age ( $<6$ years) and overweight/obesity at diagnosis were the best predictors of obesity at adult height in a study of 456 childhood ALL and lymphoma survivors, 431 of whom had ALL [30]. That study further concluded that BMI weight category at diagnosis, rather than type of CNS treatment received, predicted adult weight in long-term survivors of childhood hematologic malignancies. Zhang et al. reported that weight status at diagnosis and BMI z-score at diagnosis were both significant predictors for being overweight/obese at the end of treatment in pediatric ALL survivors [31]. They found that patients who were overweight/obese at diagnosis were 11.9 times more likely to be overweight/obese at the end of treatment than those who were underweight or had healthy weight at diagnosis. Moreover, sex, receiving CRT, and age at diagnosis were not significant predictors of BMI z-score in survivors of pediatric ALL during or after treatment. In the present study, we also did not observe any significant correlation between the risk of being overweight or obese and age at diagnosis, CRT, and sex. Additionally, Asner et al. showed an association between abnormal maternal BMI and overweight/obesity in long-term survivors of childhood ALL, except for overweight/obesity at diagnosis, while age at diagnosis, sex, cumulative dose of steroids, and paternal BMI showed no association [32]. In a previous study of 33 ALL survivors, 25 of whom were female, it was found that $56 \%$ of female survivors were obese and $59 \%$ of them had an obese mother [33]. Considering the risk of longterm excessive weight gain in childhood ALL survivors including overweight/obesity at diagnosis and abnormal maternal BMI, rather than CRT, corticosteroids, age at diagnosis, and sex, the patient's familial and genetic characteristics are likely to be risk factors leading to overweight/obesity for this population.

ALL survivors are reported to have a 4-fold excess risk of mortality secondary to cardiovascular events compared to the 
general population. In addition to cardiomyopathy associated with anthracyclines, ALL survivors have also been shown to have atherosclerotic disease, which led to an investigation of conventional risk factors for cardiovascular disease including diabetes mellitus, dyslipidemia, obesity, and metabolic syndrome [13]. In the present study, the second and third most common endocrine complications were overweight/obesity (33.3\%) and dyslipidemia (23.3\%), whereas insulin resistance (11.7\%) and hypertension (8.3\%) were the fourth and fifth most common endocrine complications. Because childhood ALL survivors will be young at the time of completion of treatment, as in the present study (median age: 11.7 years), many treatment-related adverse events may not become clinically apparent until the survivor gets older in the context of cardiovascular disease development, and thus preventive strategies including medical interventions and lifestyle modifications such as eating a healthful diet, regular physical activity, and avoiding cancer-associated habits including smoking or excessive alcohol consumption can help reduce the risk factors leading to cardiovascular late events.

ALL survivors treated with conventional CRT doses do not usually develop other central endocrinopathies, such as central adrenal insufficiency, hyperprolactinemia, gonadotropin insufficiency, or central (secondary) hypothyroidism. However, primary hypothyroidism can occur after cranial, craniospinal, and total body irradiation because of direct exposure of the thyroid gland to radiation, even at low doses [2]. Precocious puberty is another late effect of CRT in doses of 18 to $24 \mathrm{~Gy}$, and it is more common in girls. However, most female ALL survivors experience menarche at a normal age, which was confirmed in two large cohorts $[34,35]$. Reduction or elimination of CRT in treatment of childhood ALL in recent protocols is another reason for favorable outcome in the context of central endocrinopathy development $[4,5,6]$. In the present study, there were no patients diagnosed with adrenal insufficiency, and the frequency of patients with hypothyroidism and subclinical hypothyroidism (compensated) was $1.7 \%$ and $3.3 \%$, respectively. Only two of $60 \mathrm{ALL}$ survivors developed precocious puberty; both were girls and one received CRT.

\section{Conclusion}

In conclusion, a high frequency of endocrine long-term adverse events occurred in the current study. In achieving $>90 \%$ of 5-year survival rates for children with ALL diagnosed at 14 years of age or younger, there has been an increase in the number of children and adolescents cured of ALL. In this context, considering the high prevalence of late adverse effects as a consequence of ALL or its therapy as compared to the general population, long-term surveillance of this population is important to better understand the incidence of late-occurring events and define high-risk features that can facilitate the development of intervention strategies for early detection and prevention, which can lead to an improvement of care and quality of life for this growing population.

\section{Ethics}

Ethics Commitee Approval: The research has been approved by Ankara Children's Hematology and Oncology Hospital's ethics commitee (approval number 2013-051) and informed consent was obtained from the parents of the patients. The manuscript has been seen and approved by all of the authors.

\section{Author Contributions}

Concept: Cengiz Bayram, Neşe Yaralı, Betül Tavil; Design: Cengiz Bayram, Neşe Yaralı, Betül Tavil, Fatma Demirel; Data Collection or Processing: Cengiz Bayram, Neşe Yaralı, Ali Fettah, Fatma Demirel; Analysis or Interpretation: Cengiz Bayram, Neşe Yaralı, Ali Fettah, Fatma Demirel; Literature Search: Cengiz Bayram, Neşe Yaralı, Ali Fettah, Fatma Demirel, Betül Tavil, Abdurrahman Kara, Bahattin Tunç; Writing: Cengiz Bayram, Neşe Yaralı, Ali Fettah, Fatma Demirel, Betül Tavil, Abdurrahman Kara, Bahattin Tunç.

Conflict of Interest: The authors of this paper have no conflicts of interest, including specific financial interests, relationships, and/or affiliations relevant to the subject matter or materials included.

\section{References}

1. Ness KK, Armenian SH, Kadan-Lottick N, Gurney JG. Adverse effects of treatment in childhood acute lymphoblastic leukemia: general overview and implications for long-term cardiac health. Expert Rev Hematol 2011;4:185197.

2. Nathan PC, Wasilewski-Masker $\mathrm{K}$, Janzen LA. Long-term outcomes in survivors of childhood acute lymphoblastic leukemia. Hematol Oncol Clin North Am 2009;23:1065-1082.

3. Shankar SM, Marina N, Hudson MM, Hodgson DC, Adams MJ, Landier W, Bhatia S, Meeske K, Chen MH, Kinahan KE, Steinberger J, Rosenthal D; Cardiovascular Disease Task Force of the Children's Oncology Group. Monitoring for cardiovascular disease in survivors of childhood cancer: report from the Cardiovascular Disease Task Force of the Children's Oncology Group. Pediatrics 2008;121:e387-396.

4. Inaba H, Greaves M, Mullighan CG. Acute lymphoblastic leukaemia. Lancet 2013;381:1943-1955.

5. Veerman $A J$, Kamps WA, van den Berg $H$, van den Berg $E$, Bökkerink JP, Bruin MC, van den Heuvel-Eibrink MM, Korbijn CM, Korthof ET, van der Pal $\mathrm{K}$, Stijnen $\mathrm{T}$, van Weel Sipman MH, van Weerden JF, van Wering ER, van der Does-van den Berg A; Dutch Childhood Oncology Group. Dexamethasonebased therapy for childhood acute lymphoblastic leukaemia: results of the prospective Dutch Childhood Oncology Group (DCOG) protocol ALL-9 (1997-2004). Lancet Oncol 2009;10:957-966.

6. Pui CH, Campana D, Pei D, Bowman WP, Sandlund JT, Kaste SC, Ribeiro RC, Rubnitz JE, Raimondi SC, Onciu M, Coustan-Smith $E$, Kun LE, Jeha S, Cheng C, Howard SC, Simmons V, Bayles A, Metzger ML, Boyett JM, Leung W, Handgretinger R, Downing JR, Evans WE, Relling MV. Treating childhood acute lymphoblastic leukemia without cranial irradiation. N Engl J Med 2009;360:2730-2741.

7. Howard SC, Pui CH. Endocrine complications in pediatric patients with acute lymphoblastic leukemia. Blood Rev 2002;16:225-243. 
8. Pui CH, Boyett JM, Rivera GK, Hancock ML, Sandlund JT, Ribeiro RC, Rubnitz JE, Behm FG, Raimondi SC, Gajjar A, Razzouk B, Campana D, Kun LE, Relling MV, Evans WE. Long-term results of Total Therapy studies 11, 12 and 13A for childhood acute lymphoblastic leukemia at St Jude Children's Research Hospital. Leukemia 2000;14:2286-2294.

9. Neyzi O, Furman A, Bundak R, Gunoz H, Darendeliler F, Bas F. Growth references for Turkish children aged 6 to 18 years. Acta Paediatr 2006;95:1635-1641.

10. William AN. Disorders of lipoprotein metabolism and transport. In: Kliegman RM, Stanton BF, St. Geme JW, Schor NF, Behrman RE, (eds). Nelson Textbook of Pediatrics, 19th ed. Philadelphia, Elsevier Saunders, 2011.

11. Kurtoğlu $S$, Hatipoğlu N, Mazıcıoğlu M, Kendirici M, Keskin $M$, Kondolot $M$. Insulin resistance in obese children and adolescents: HOMA-IR cut-off levels in the prepubertal and pubertal periods. J Clin Res Pediatr Endocrinol 2010;2:100-106.

12. Keskin $M$, Kurtoglu $S$, Kendirci $M$, Atabek ME, Yazici C. Homeostasis model assessment is more reliable than the fasting glucose/insulin ratio and quantitative insulin sensitivity check index for assessing insulin resistance among obese children and adolescents. Pediatrics 2005;115:e500-503.

13. Nottage KA, Ness KK, Li C, Srivastava D, Robison LL, Hudson MM. Metabolic syndrome and cardiovascular risk among long-term survivors of acute lymphoblastic leukaemia - from the St. Jude Lifetime Cohort. Br J Haematol 2014;165:364-374.

14. Canaris GJ, Manowitz NR, Mayor G, Ridgway EC. The Colorado Thyroid Disease Prevalence Study. Arch Int Med 2000;160:526-534.

15. Greenspan FS. Greenspan's Basic \& Clinical Endocrinology, 9th ed. New York, McGraw-Hill Medical, 2011.

16. Misra M, Pacaud D, Petryk A, Collett-Solberg PF, Kappy $M$; Drug and Therapeutics Committee of the Lawson Wilkins Pediatric Endocrine Society. Vitamin D deficiency in children and its management: review of current knowledge and recommendations. Pediatrics 2008;122:398-417.

17. Goksen D, Darcan S, Coker M, Kose T. Bone mineral density of healthy Turkish children and adolescents. J Clin Densitom 2006;9:84-90.

18. Haddy TB, Mosher RB, Reaman GH. Late effects in long-term survivors after treatment for childhood acute leukemia. Clin Pediatr (Phila) 2009;48:601608.

19. Oeffinger KC, Mertens AC, Sklar CA, Kawashima T, Hudson MM, Meadows AT, Friedman DL, Marina N, Hobbie W, Kadan-Lottick NS, Schwartz CL, Leisenring W, Robison LL; Childhood Cancer Survivor Study. Chronic health conditions in adult survivors of childhood cancer. $N$ Engl J Med 2006;355:1572-1582.

20. Geenen MM, Cardous-Ubbink MC, Kremer LC, van den Bos $C$, van der Pal HJ, Heinen RC, Jaspers MW, Koning CC, Oldenburger $F$, Langeveld $N E_{\text {, }}$ Hart AA, Bakker PJ, Caron HN, van Leeuwen FE. Medical assessment of adverse health outcomes in long-term survivors of childhood cancer. JAMA 2007;297:2705-2715.
21. Blaauwbroek R, Groenier KH, Kamps WA, Meyboom-de Jong B, Postma A. Late effects in adult survivors of childhood cancer: the need for life-long follow-up. Ann Oncol 2007;18:1898-1902.

22. Wasilewski-Masker K, Kaste SC, Hudson MM, Esiashvili N, Mattano LA Meacham LR. Bone mineral density deficits in survivors of childhood cancer: long-term follow-up guidelines and review of the literature. Pediatrics 2008;121:e705-e713.

23. Looker AC, Dawson-Hughes B, Calvo MS, Gunter EW, Sahyoun NR. Serum 25-hydroxyvitamin $D$ status of adolescents and adults in two seasonal subpopulations from NHANES III. Bone 2002;30:771-777.

24. Saintonge $S$, Bang $H$, Gerber LM. Implications of a new definition of vitamin D deficiency in a multiracial US adolescent population: the National Health and Nutrition Examination Survey III. Pediatrics 2009;123:797-803.

25. Akman AO, Tumer L, Hasanoglu A, Ilhan M, Caycı B. Frequency of vitamin D insufficiency in healthy children between 1 and 16 years of age in Turkey. Pediatr Int 2011;53:968-973.

26. Andıran N, Çelik N, Akça H, Doğan G. Vitamin D deficiency in children and adolescents. J Clin Res Pediatr Endocrinol 2012;4:25-29.

27. Choudhary A, Chou J, Heller G, Sklar C. Prevalence of vitamin D insufficiency in survivors of childhood cancer. Pediatr Blood Cancer 2013;60:1237-1239.

28. Oeffinger KC, Mertens AC, Sklar CA, Yasui Y, Fears T, Stovall M, Vik TA, Inskip PD, Robison LL; Childhood Cancer Survivor Study. Obesity in adult survivors of childhood acute lymphoblastic leukemia: a report from the Childhood Cancer Survivor Study. J Clin Oncol 2003;21:1359-1365.

29. Dalton VK, Rue M, Silverman LB, Gelber RD, Asselin BL, Barr RD, Clavell LA, Hurwitz CA, Moghrabi A, Samson Y, Schorin M, Tarbell NJ, Sallan SE, Cohen LE. Height and weight in children treated for acute lymphoblastic leukemia: relationship to CNS treatment. J Clin Oncol 2003;21:2953-2960.

30. Razzouk BI, Rose SR, Hongeng $S$, Wallace $D$, Smeltzer MP, Zacher M, Pui $\mathrm{CH}$, Hudson MM. Obesity in survivors of childhood acute lymphoblastic leukemia and lymphoma. J Clin Oncol 2007;25:1183-1189.

31. Zhang FF, Rodday AM, Kelly MJ, Must A, MacPherson C, Roberts SB, Saltzman E, Parsons SK. Predictors of being overweight or obese in survivors of pediatric acute lymphoblastic leukemia (ALL). Pediatr Blood Cancer 2014;61:1263-1269.

32. Asner S, Ammann RA, Ozsahin H, Beck-Popovic M, von der Weid NX. Obesity in long-term survivors of childhood acute lymphoblastic leukemia. Pediatr Blood Cancer 2008;51:118-122.

33. Shaw MP, Bath LE, Duff J, Kelnar CJ, Wallace WH. Obesity in leukemia survivors: the familial contribution. Pediatr Hematol Oncol 2000;17:231-237.

34. Mills JL, Fears TR, Robison LL, Nicholson HS, Sklar CA, Byrne J. Menarche in a cohort of 188 long-term survivors of acute lymphoblastic leukemia. J Pediatr 1997;131:598-602.

35. Chow EJ, Friedman DL, Yasui Y, Whitton JA, Stovall M, Robison LL, Sklar CA. Timing of menarche among survivors of childhood acute lymphoblastic leukemia: a report from the Childhood Cancer Survivor Study. Pediatr Blood Cancer 2008;50:854-858. 